\title{
Alica Petrasová
}

\section{Literacy cubed - focus on Roma families}

Streszczenie: Autorka prezentuje europejski projekt partnetski Alfabetyzacja do potęgi trzeciej - w centrum uwagi rodziny romskie $\left(\right.$ LIT $\left.^{3}\right)$. Program wdrożono pilotażowo w trzech krajach: Czarnogórze, Rumunii i Słowacji, w okresie od grudnia 2013 roku do listopada 2015 roku. Projekt wspomaga rozwój umiejętności czytelniczych i dotyczących instrukcji zdrowotnych trzech pokoleń: dzieci ze szkół podstawowych (wiek 6-11 lat), ich rodziców/opiekunów oraz ich dziadków. Celem projektu LIT ${ }^{3}$ było podniesienie poziomu edukacji ogólnej dzieci romskich. Organizacja pozarządowa Orawskie Stowarzyszenie Demokratycznej Edukacji jest głównym koordynatorem i wdrażającym projekt na Słowacji. W artykule zaprezentowano doświadczenia zespołu projektowego, zdobyte przy zaangażowaniu wszystkich biorących udział w projekcie LIT ${ }^{3}$ w mieście Dolný Kubín (Słowacja).

Wyrazy kluczowe: rodzina romska, alfabetyzacja rodzinna - czytanie i zdrowie, dzieci ze środowisk społecznie defaworyzowanych

\section{Introduction}

Europe 2020 is a strategic vision of Europe for the $21^{\text {st }}$ century. It explains how the EU can turn into a smart, sustainable and socially inclusive economy delivering a high level of employment, productivity and social cohesion. Cohesion policy operates where people live. It plays a key role in achieving the strategic objectives for the year 2020, while ensuring that those at risk of exclusion from the society will not remain on the periphery (www.europskaunia.sk).

The fact that the Roma population in contrast to the European one is young is mentioned in the document of EU framework for national strategies for the Roma inclusion, which is a part of the Europe 2020 strategy. Nearly 36 percent of Romanies are in fact younger than 15 years compared to nearly 16 percent of EU citizens. Likewise, the average age of the Roma is 25 years, while it is 40 years in the EU. Europe looses labor when it does 
not use the Roma potential. Therefore, a key aspect in regard to this will be particular emphasis on their higher level of education in order to qualify for better jobs. Currently, the member states of the European Union still have the main responsibility for the integration of the Roma population, because the major challenges that are faced by the Roma fall within their jurisdiction. In particular, this concerns the access to the quality of education, the labour market, housing, basic services, and health care. The local and regional authorities are responsible for those policies in most cases within states. It means that the authorities at the national and regional levels are responsible for the inclusion of the Roma.

The Slovak Republic is obligated to comply with the Convention on the Rights of the Child ${ }^{1}$, which declares that education must lead to the development of the child's personality, talents and mental functions to the most possible extent. Education must prepare the child for an active life in adulthood in a free society and must enhance the respect for the child's parents, the own cultural identity, language, values and cultural background, as well as values of others. Education of the Roma children and learners, based on their social situation, the need to improve their educational level and ensure participation in social life with success on the labor market, requires a complex solution of the problem from the perspective of children and learners from the socially disadvantaged environment in the system of school education. Slovakia ranks the highest among the countries with the greatest differences in the students' results by the achieved level of parental education. The fact that Slovakia belongs to the countries with the greatest influence of students socio-economic background on their performance is also an important finding (PISA, 2003, 2006, 2012, 2015).

The school education of Romani learners is specific and it requires taking into consideration some preconditions for education with which learners begin their educational trajectory. School, teachers who work with these learners, should know the socio-educational characteristics of Romani pupils from the environment of social exclusion, because it is their character that determines the course itself, the educational factors and, subsequently, the objective of the educational path. To emphasize the specificity of school education (including the importance of pre-school education, school maturity and readiness, possible educational or didactic difficulties, educational

1 The General Assembly of the United Nations adopted the Convention on the Rights of the Child on $20^{\text {th }}$ of November 1989. 
needs, methods and models of management in the educational process, but also the necessity of active cooperation with family, or alternatively cooperation with non-profit sector) is hopefully not necessary here (Kaleja, 2011, 2013, 2014, 2015).

\section{About the Project}

Project Literacy Cubed - Focus on Roma Families (hereinafter: Project LIT ${ }^{3}$ ) was aimed to develop and disseminate effective strategies to promote family literacy (the support of reading and health education) in Roma communities and to increase the educational success of Roma children at school and to improve the literacy of adult Roma. The goal of the project was to influence habits and attitudes of children and to encourage their parents to participate in education.

Project LIT ${ }^{3}$ was implemented from $12^{\text {th }}$ January 2013 to $30^{\text {th }}$ November 2015 through a partnership of 3 countries (Romania, Montenegro and Slovakia). The work was performed in three locations: in the city of Cluj-Napoca, Romania, where two Roma families, living in two different neighborhoods, joined the project, but both were populated by an overwhelming majority of Romanies with low socio-economic status (in fact one of the "neighbourhoods"' is an urban landfill, which helps people to make a living by collecting recyclable materials); in the city of Dolny Kubín, Slovakia, where it was implemented mostly with integrated Roma families; in Podgorica, Montenegro, where the project was focused on the Roma families living in Konik refugee camp on the outskirts of the city.

The project benefits from a diversed partnership of a research institution, an international umbrella organization, and three national NGOs, as well as six associated partners (5 Roma organizations and 1 educational office). Including stakeholders in two European-level partnership meetings will provide added value to this European cooperation project. The fact that stakeholders from European countries that are not involved in the project partnership will enhance the European dimension of the project and increase its chances of impact at the European level. The project's view on policies and practical aspects related to Roma families and education, as well as family literacy in general will be enriched by the European partnership.

The dissemination strategy has been built on the basis of partners' dissemination plans. The strategy includes clear indicators of successful outreach by the categories of direct and indirect beneficiaries. The number of 
website visitors, participants in conferences, workshops, stakeholders' WG meetings, and round table debates will be carefully planned and monitored. Qualitative indicators are defined to ensure the optimal exploitation of results. Based on a thorough needs analysis, the family literacy program will be tested to ensure the evidence base which will inform the family about the promoted literacy policy and which will be the foundation of the local strategies for family literacy. The implementation plan for Project $\mathrm{LIT}^{3}$ focuses on: research-based policy recommendations for European and local decision-makers; stakeholder engagement; development of family literacy programme and family literacy programme testing.

In the project, 48 Roma primary school learners from 4 schools ( 2 in $\mathrm{RO}$, 1 in $\mathrm{MN}$ and 1 in SK) and 72 adults (the children's parents and grandparents) developed their literacy skills by attending 48 hours of literacy workshop activities. 48 secondary school students acted as reading buddies for Roma children. Three local working groups of stakeholders developed local strategies under the guidance of the project team. 170 doctor's surgeries received flyers to promote health literacy in Roma communities (www.lit3-project.eu) ${ }^{2}$.

Non-government organization Orava Association for Democratic Education $^{3}$ was the main coordinator and implementer of the project in Slovakia. What is presented in this study are the experiences of the project team with the engagement of the stakeholders of the Literacy Cubed - Focus on the Roma families project in the city of Dolný Kubín (Slovakia) ${ }^{4}$.

2 The summary report presents the findings of the evaluation conducted by the UCL Institute of Education (IOE) of a pilot Family Literacy Programme carried out as part of the Literacy Cubed: Focus on Roma Families project. See: http://discovery. ucl.ac.uk/1475761/.

3 Orava Association for Democratic Education (Orava ADE) is a non-government organization that has made efforts to improve the Slovak education system by promoting cooperation and communication between communities of teachers, schools, universities, libraries, non-government and government educational institutions from 1995. The Orava Association elaborates the training programmes and materials for teachers and parents. It organizes conferences, seminars, round table negotiations and regular actions to promote reading (eg. Week of Loud Reading). The Orava Association is a member of the several national and international networks and enjoys longterm partnership with the Ministry of Education of the Slovak Republic, the National Council of the Slovak Republic and other state administration organs, regional and local municipality and non-government organizations.

4 The author of the paper has been an active investigator of the project Literacy Cubed - Focus on Roma Families. 


\section{The stakeholders engagement as part of the local strategy for supporting family literacy}

The aim of the project Literacy Cubed - Focus on Roma Families was to develop and support effective policies at the local level that affect the development of family literacy (readership and health literacy) in local communities. As the title says (The Literacy Cubed), the programme connected three generations (children-parents-grandparents). More than 20 children at primary school age, 12 adults (parents and grandparents). 10 children at older school age (as friends to read), 8 volunteers and 5 trainers were involved in the family literacy program in Dolny Kubín.

When authors of the Project $\mathrm{LIT}^{3}$ started to think how to make this project much more than a family literacy program in local community, the idea emerged to involve various key players or stakeholders. There were representatives of institutions, organizations and individuals with legitimate interest at the local level in the Project $\mathrm{LIT}^{3}$. Among the groups of the project stakeholders, there were - apart from Roma families - the representatives of local authorities, for example - the Town Hall, local and regional educational authorities, social services, health authorities; schools and universities preparing the trainers, social workers and medical staff; families, parents and parents' associations; teaching assistants, doctor surgeries, hospitals, health care professionals; libraries and librarians; social workers; education and health non-government organizations, charities, donors, voluntary organizations, volunteers and publishers.

The main task was to bring together a group of experienced and influential individuals who would represent their institutions and would add the family literacy in their job describtion. It was a step into the unknown for our project team since their participation should be voluntary, free and it required their engagement. We were aware that if this project is to be active at the local level, we needed to use all our local contacts and th knowledge of the local conditions. Therefore, the project team had made a list of potential local stakeholders, individuals or institutions that we contacted later.

Inviting the potential key players was realized mainly through personal meetings with the heads of various bodies or institutions. The project team members tried to be precise in this, and although they could not always find senior executives first, they insisted to take part on the preparatory personel meeting at least. They were not sure how the invited people will respond 
because each project is specific in something. However, they believed in the project idea and the work they had performed, thus - it was not difficult for them to persuade, communicate the ideas and to gain people in this way. Therefore, they hoped that people who are asked know other key players and would give them more contacts or designate people from their organizations. This turned out to be true. They also invited people and institutions that had been involved in the first phases of the project - to map the local needs.

The team was aware that it was important to create a higly competent and committed group of local stakeholders, the particular members of the project team had arranged personal meetings with those who were labeled as "musts" on the organizers' list. The team did not want to lose the representatives of the most important institutions because of some unforseen reasons or due to unclear communication. Moreover, they realized that the space where they worked was not large (about 20000 inhabitants), therefore they could not afford to lose any important person. So they met them personally prior to the invitation at the first meeting of the working group. They believed that a face-to-face meeting can not be replaced by any other means of contact. The meetings allowed them to introduce themselves and speak clearly about the current projects and to try to explain the project objectives, expectations, the persons' potential roles as well as to explore how the joint effort might be intensified by future cooperation. In addition, it was better to explain orally what kind of experts and persons the project needed in the working group 5 . The members of the project team were aware, due to the previous experiences, that the first meeting is always critically important for further cooperation. Therefore, they paid attention to such aspects as: the place, time, form of invitation, programme, meeting reminders a few days in advance, providing light lunch and snack, appropriate presentation of the project, etc. They asked the representatives of the Town Hall to provide them with a meeting room on their premises for choosing a place that would be easily available to each of the stakeholders and would ensure sufficient respect and dignitiy for the working group. Ensuring the meeting room in the Town Hall was important for the implementation of the project and thus for demonstrating support for the project by the local municipality. Most of the project team meetings were held in an ordinary meeting room of the munic-

5 Therefore, the term "group of experts" was used initially. Mostly managers of the offices and institutions were commissioned to the working group. The term "stakeholders" was later introduced in English which espresses this category of persons more accurately. 
ipality. One meeting took place in the more prestigious meeting room of the Mayor. In addition, the seat of the local television is in the same building, so it was easier to gain publicity for the project.

The cooperation with the officials of the participating institutions was formally secured by signing of the Memorandum. The Memorandum of cooperation was signed with each institution after the first meeting so that the stakeholders could have more time to consider their other commitments. Except for one, all institutions remained until the end. It turned out to be a wise achievement to pay particular attention to the details of the Memorandum because it was possible to refer to the project in the course of its realization. The Memorandum comprised specific roles for the particular stakeholders unless they were foreseeable at that time, such as providing a meeting room, allowing at least one representative of the institution to participate in the working group meetings, allowing the representatives of the organization to travel woth the aom of the international negotiations of the project, etc. These roles were included in the text of the Memorandum, noting that any other form of cooperation will be additionally agreed subsequently in time by both sides. The Memorandum was easy to update later when further specific measures were clear. Neverthless, it seem to be true that if the cooperation works well, such formalization may not always necessary. The main objective of the cooperation within the framework of the permanent working group was to develop a local strategy to promote family literacy of the local Roma community. The strategy began to form on the fourth meeting, at which the project team prepared all available resources, such as: the outcomes and recommendations of the project, a framework for strategy development, and so on. The team worked in smaller groups for better effectivness and then the results were shared across the entire working group.

\section{Conclusion}

The project team did not know what to expect from this type of work at the beginning and how to avoid disappointment, they were also satisfied with less ambitious expectations. They were aware that we, as a non-government organization which initiated the project, had no power to require any commitments of the stakeholders. The team felt that they had to respect the experience of our key players, to be honest and open in expressing their expectations and commitment to achieve the objective. The recognition and celebration of even the smallest success, gave the team members the power 
to move forward and to do a good job at meetings or via e-mail communication. What was shared with each other and recognized was each step that had been made for the project support by any interested party.

The influential individuals can be very useful. The success came with the acquisition of the most active stakeholders as the team approached closer the leaders of institutions who usually authorized other competent persons to represent their institution. The team also tried to use the right meeting place - the conference room at the seat of the local authorities served this purpose very well. It should be agreed that all groups of stakeholders should be equally represented in the dialogue in order to remain credible to the other stakeholders and the wider public. The team insisted on each stakeholder's having the space and opportunity to express their thoughts at meetings and to have their opinions and recommendations recorded. After the meeting, the protocol was send via e-mail so that everyone could either approve what had been recorded or to ask the interested stakeholder to supplement the explanations where necessary.

We have learned in our work that the size of the common good may be for representatives of stakeholders particularly interesting, especially if they work in the social field. As they expressed themselves, they joined the working team because the objectives and problems that this project was facing. The solution through family literacy was a relatively new concept, even if they saw some harbringers in that area, too. The stakeholders also appreciated the opportunity to meet the representatitves of other institutions with similar objectives with whom they could share their experiences. At the end of the project, they expressed their desire not to waste their joint effort, which lasted nearly two years, but they wished to have a good and feasible common strategy that would continue the started work and which would have the potential to engage and be beneficial to the whole local community, Roma and non-Roma, too.

The policy proposals oriented to improving the integration of the Roma into the mainstream society have a fundamental flaw. They are based on the assumption that there are some specific problems of Roma to be addressed. The work with Roma children and their families can be successful only if the wider local community is involved - parents, counseling centers, social workers, institutions and organizations dealing with family problems of social exlusion, activation staff of the community, and so on. The community is the environment or group of people who are, regardless of the differences, able to appreciate differences and allow them openly and effectively to communi- 
cate and work together to achieve common objectives. The word community is often used as a synonym for congregation. The word community comes from the Latin word root common with communicare, communication communicate.

The phenomenon of community allows to create and experience non-hierarchical, very deep interpersonal bonds, difficult to implement in the current social environment. It allows people to accept, transcend and celebrate their differences and divergences that enable them to communicate effectively, openly and to cooperate by achieving objectives that have been set for the common good. As a consequence, many members of the group, generating a sense of community, experience the feeling of their uniqueness and profound common unity that is rarely or never felt in other groups.

\section{Bibliography}

About the Project, http://www.lit3-project.eu/about-the-project/ (07.11. 2016).

Act No. 245/2008 Coll. on education; changes and amendments to certain laws. http://www.minedu.sk/data/USERDATA/Legislativa/ Zakony/2008_245.pdf.

Carpentieri, J. D., Litster, J. and Mallows, D. 2015. Literacy Cubed Need Analysis Report. Brussel: European Commission.

Kaleja, M. 2011. Roma and School Versus Parents and Pupils. Ostrava: PdF Ostrava universities in Ostrava.

Kaleja, M. 2013. Determinants of the Valued Constructs in Education of Roma Pupils in Primary Schools. Ostrava: PdF Ostrava Universities in Ostrava. Kaleja, M. 2014. Education Determinants of Socially Excluded Pupils of Primary Schools from the Perspective of Special Education. Ostrava: PdF Ostrava Universities in Ostrava.

Kaleja, M. 2015. Unprepared Teacher and Pupil from the Social Exclusion Environment. Opava: CEV, FVP Slezské University in Opava.

Kovacs M. et al. 2015. The Shareholders Involving in the Development and Implementation of Effective Policy of Family Literacy. Dolný Kubín: Vrábel' Printer.

Petrasová, A. 2011. The content and Process of Education. In: Petrasová, A. ed. Answers to Questions on (de)Segregation of Roma Students in Slovak Education System. Bratislava: Open Society Foundation. 
Petrasová, A. and Porubský, Š. 2013. The Educational Paths of Roma Pupils from Socially Disadvantaged Backgrounds. Bratislava: OSF. PISA SK 2003, 2006, 2009, 2012 and 2015. National Report. Bratislava: ŠPÚ. The Europe 2020 Strategy, http://www.europskaunia.sk/strategia-europa-2020 (15.11. 2016).

\section{Literacy cubed - focus on Roma families}

Abstract: The author presents the European partnership project Literacy Cubed - Focus on Roma Families. The programme was piloted in three countries: Montenegro, Romania and Slovakia from December 2013 to November 2015. The LIT ${ }^{3}$ project enhances the development of reading and health literacy skills of three generations: primary school children (aged 6-11), their parents/carers and their grandparents. The goal of $\mathrm{LIT}^{3}$ was to raise the attainment level of Roma children in general education. A non-government organization Orava Association for Democratic Learning is the main coordinator and implementer of the project in Slovakia. What has been presented in the article are the experiences of the project team which occurred with the engagement of all stakeholders of the Literacy Cubed - Focus on Roma families (LIT3) project in the city of Dolný Kubín (Slovakia).

Keywords: Roma family, family literacy - reading and health, children from socially disadvantaged backgrounds 